\title{
Road traffic accidents on Senai-Desaru expressway
}

\author{
Nordiana Mashros ${ }^{1}$, SittiAsmah Hassan ${ }^{1}$, Haryati Yaacob ${ }^{1}$, Mohd Shahrir Amin Ahmad ${ }^{2}$, \\ Ismail Samat ${ }^{3}$, Othman Che Puan ${ }^{1}$, Norhidayah Abdul Hassan ${ }^{1}$, Nor Zurairahetty Mohd \\ Yunus $^{1}$, and Zaiton Haron ${ }^{1}$ \\ ${ }^{1}$ School of Civil Engineering, Faculty of Engineering, Universiti Teknologi Malaysia, 81310 Skudai, \\ Johor \\ ${ }^{2}$ Malaysian Highway Authority, KM-6, Jalan Serdang-Kajang, 43000 Kajang, Selangor \\ ${ }^{3}$ Kompleks Pejabat Pentadbiran, KM 22 Lebuhraya E 22, 81800 Ulu Tiram, Johor
}

\begin{abstract}
Understanding and prioritising crash contributing factors is important for improving traffic safety on the expressway. This paper aims to identify the possible contributory factors that were based on findings obtained from crash data at Senai-Desaru Expressway (SDE), which is the main connector between the western and eastern parts of Johor, Malaysia. Using reported accident data, the mishaps that had occurred along the 77.2 $\mathrm{km}$ road were used to identify crash patterns and their possible related segment conditions. The Average Crash Frequency and Equivalent Property Damage Only Average Crash Frequency Methods had been used to identify and rank accident-prone road segments as well as to propose for appropriate simple and inexpensive countermeasures. The results show that the dominant crash type along the road stretches of SDE had consisted of run-off-road collision and property damage only crashes. All types of accidents were more likely to occur during daytime. Out of the 154 segments, the 4 most accident-prone road segments had been determined and analysed. The results obtained from the analyses suggest that accident types are necessary for identifying the possible causes of accidents and the appropriate strategies for countermeasures. Therefore, this accident analysis could be helpful to relevant authorities in reducing the number of road accidents and the level of accident severity along the SDE.
\end{abstract}

\section{Introduction}

Every year, as many as 1.25 million people die on the road and another 20-50 million people sustain non-fatal injuries as a result of road traffic collisions or crashes [1]. Even worse, if appropriate actions are not taken, road traffic injuries are estimated to become the third leading cause of death and injury by 2020 [2]. According to The World Bank, most of the fatalities had occurred in low and middle income countries (LMICs). Despite having only about half of the world's motor vehicle, these countries now account for 90 per cent of the worldwide road traffic deaths and non-fatal road crash injuries [1,3]. This problem had increased at a fast rate in LMICs as a result of a combination of factors, which include rapid motorisation, poor road and traffic infrastructure as well as the behaviour of 
road users [4,5]. A contrasting trend, however, is observed in many high-income countries, where multiple intervention strategies and projects had contributed to a significant reduction of the burden of road traffic injuries [6-8]. Some examples of effective interventions had included enforcement of legislation on speed control and alcohol consumption, the promotion of seatbelt and helmet utilization, safer vehicle design and better control in the use of roads and vehicles [9].

Road crashes often induce traffic congestions. Shefer and Rietveld [10] had hypothesised that the high average speed of traffic on a less congested road network would most likely result in more serious injuries or fatalities, while less fatalities and serious injuries would occur in a congested road network, where the traffic is slower. This increased traffic congestion may lead to more accidents due to increased traffic volume; however, those accidents may be less severe. This suggests that the total external cost of accidents may be less in a congested situation than in an uncongested situation. However, this has posed a potential dilemma for transport policy makers since it would appear that traffic congestion can improve road safety [11]. Past studies had also shown that over 30 per cent of the daily delay was caused by road crashes [12].

Many studies had been conducted in the area of road safety, especially on motorways and expressways. This was due to the historical data that suggest the level of accident severity to be higher than those generally occurred on normal roads. Therefore, the aim of this study is to identify the possible contributory factors that were based on findings obtained from crash data at Senai-Desaru Expressway (SDE) and to propose suggestions for safety improvement.

This research begins with a discussion on the factors commonly reported in road accidents, which is then followed by an explanation of the methodology used in the study. Results from the analysis along with discussion on the findings are then presented before concluding with suggestions for future research.

\section{Literature review}

Road accidents are unpredictable events, which can occur in any circumstances [13]. As such, it can be defined by a set of variables that are mostly of a discrete nature. Road traffic accident occurs when a vehicle that is moving along a roadway collides with another vehicle, pedestrian or other stationary obstruction. The exposure to potential road traffic injury had increased profoundly as a result of rapid motorization, poor road conditions, rapid population growth, lack of safety features in cars, crowded roads, poor road maintenance as well as the lack of police enforcement. Apart from distractions andspeeding on the road, other causes of accidents had also been due to reckless driving, lack of proper protection, bad personal habits, social and behavioural misconduct and inconsiderate drivers of larger vehicles [14].

Road accidents that cause profound damages are occurring in almost all over the world. They are often caused by an accumulation of elements, which belong largely to four major classes of conditions: the human factor, infrastructure, vehicles and weather conditions $[15,16]$. Therefore, identifying causes of accidents and the risk factors for this problem may provide a clue to possible effective intervention and make suggestions to promote safer driving [17].

Human factors also play a very important role in road accidents. It refers to the inadequacy of the variables characterizing the human component (such as level of experience, fatigue, attention, etc.), that combines with the inadequacy of the variables characterizing the other components (road layout, vehicle, environment, traffic) to produce human errors [18]. It was reported that human factors had contributed to $41 \%$ of the road accidents in Malaysia [19], while in Saudi Arabia; the most common human factors had 
been due to speeding (65\%), driver error $(80 \%)$, violation of traffic signals at intersections (50\%) and illegal U-turns [20]. Most of the road accidents had been due to the lack of safety knowledge and traffic rules as well as the negative attitudes shown by some drivers such as impatience, carelessness and inconsiderate driving.

Vehicle defects are considered one of the most primary reasons of road traffic accidents. These vehicle defects refer to design or mechanical faults of a vehicle, which includes poor vehicle maintenance. In developing countries, it is likely that vehicle defects are more often a pronounced factor in accidents since vehicle maintenance practices as well as vehicle conditions are generally much worse. Vehicles that receive little or no servicing are accidents waiting to happen, where, among the regularly neglected components had been tyres, brakes, steering, lights and indicators. Statistics had shown that $1.3 \%$ of accidents in Japan were attributed to vehicle defects [21]. While conducting a controlled case study of fatal single vehicle crashes in Victoria that happened from December 1995 to November 1996, Haworth et al. [22] had discovered that from all of the crashed cars, 37\% of them had defects that rendered them unroadworthy. However, mechanical defects had only contributed to $3 \%$ of the crashes, where the most common defects had been due to tyre and brake glitches. This factor had contributed to 7\% of road accidents in Malaysia [19], which were due to failure of the brake system, uneven tire wear and vehicle age, among others.

Some studies had also shown road accidents to be caused by road environment factors. Road environment factors refer to traffic, road surface condition, weather and visibility conditions as well as dynamic obstacles. For these reasons, motor vehicle crash fatality rates were observed to be higher in rural areas than in urban areas. The relationship between road traffic accidents and geometric design variables, such as curvature, vertical grade, lane width, and hard-shoulder width had also been empirically investigated through statistical models in several studies [23,24]. Glennon [25] had discovered that roads with limitations of sight distance as a result of crest curves would have a $52 \%$ higher frequency of accident occurrences than roads with vertical sag curves. The grade would also have a direct impact on accident occurrences as driving visibility is reduced [26], where accident rates and its severity will be increased by following the grade levels [27].

Traffic conditions, traffic speed, traffic flow, traffic density and congestion appear to have impacts on crash frequency and severity $[11,28,29]$. In general, traffic volume changes over time. If this volume exceeds the capacity, the mean speed decreases; subsequently, if the traffic volume decreases, the mean speed increases. When the rate of variation in speed increases, it is imperative for the drivers to adjust their vehicle speed more frequently. In this case, the drivers are more likely to make a misjudgement while maintaining a safe separating distance from the other vehicles.

Adverse weather conditions such as rain, sleet, and fog had also constituted to most of the road accidents. Weather impacts traffic through several ways, among which visibility, precipitation, wind speed and temperature are of most concern. Severe weather conditions can also affect the drivers' capabilities, vehicle stability and the friction of the road [30]. The effects of adverse conditions on road transport were also observed to be immediate, but varied [31]. The past studies of Wang et al. [32] and Chen and Chen [33] had identified weather condition as a major accident factor, by which rain [34] or foggy conditions would cause a higher chance of accident. Hijar et al. [35] had also verified that driving under unusual weather conditions would have a 5.33 times greater chance of accident than driving under normal weather conditions. Other than that, the pavement condition was also found to have a significant effect on single- and multiple vehicle accident rates [36]. 


\section{Material and methods}

This paper focuses on E22 Senai-Desaru Expressway (SDE), which is an expressway in Johor, Malaysia. It is the third east-west-oriented expressway in the Iskandar Malaysia area after the Pasir Gudang Highway and the Pontian-Johor Bahru Link of the Second Link Expressway. As shown in Figure 1, the total length of Senai-Desaru Expressway is 77.2 $\mathrm{km}$, where the Kilometre Zero of the expressway is located at Senai Utama Interchange at Senai and is the fourth longest distance highway concession awarded by the Malaysian Government. This expressway is divided into three (3) packages: Package 1 that links the Senai Utama Interchange to Ulu Tiram Interchange, Package 2 that connects the Ulu Tiram Interchange to Cahaya Baru Interchange and continues up to the Pasir Gudang Interchange, also known as Pasir Gudang Connector and Package 3 that links the Cahaya Baru Interchange to Penawar Intersection. Packages 1 and 2 of this expressway are a four-lane dual carriageway, while Package 3 had utilised a two-lane single carriageway. The respective lane configurations with each of the mainline design speed and lane width are shown in Table 1.

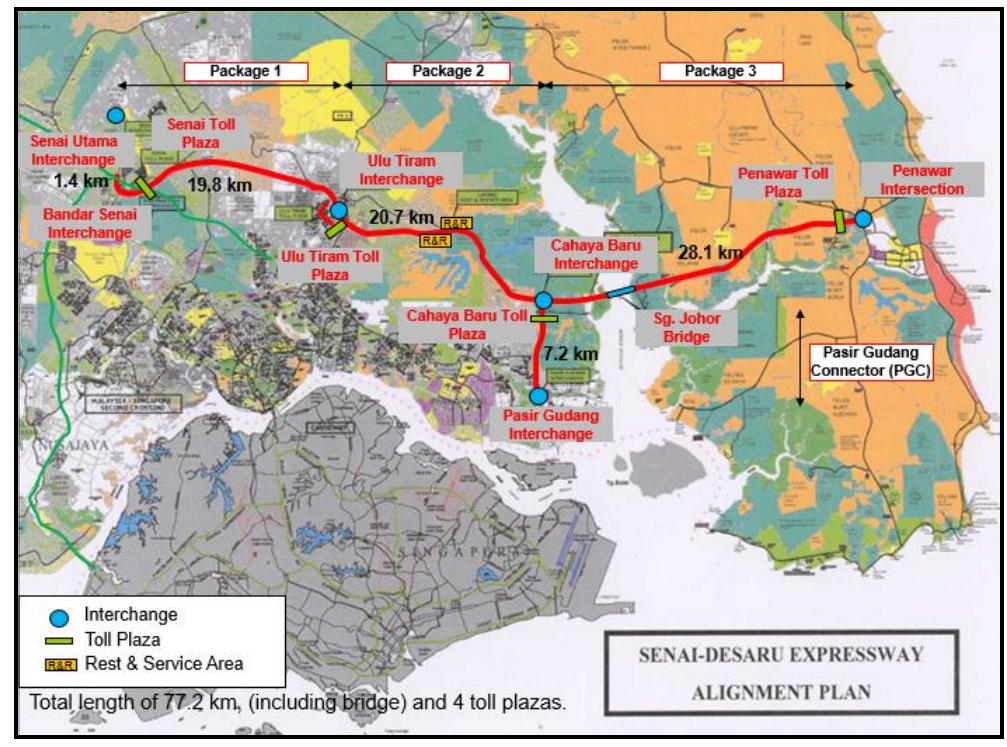

Fig. 1. Senai-Desaru Expressway.

Table 1. Road geometric design standard at SDE.

\begin{tabular}{|c|c|c|c|c|}
\hline Package & Location & Lane Configuration & $\begin{array}{c}\text { Design } \\
\text { Speed } \\
(\mathrm{km} / \mathrm{h})\end{array}$ & $\begin{array}{c}\text { Lane } \\
\text { Width (m) }\end{array}$ \\
\hline 1 & $\begin{array}{c}\text { Senai Utama Interchange - Ulu } \\
\text { Tiram Interchange }\end{array}$ & $\begin{array}{c}\text { Dual 2-lane } \\
\text { carriageway }\end{array}$ & 120 & 3.65 \\
\hline 2 & $\begin{array}{c}\text { Ulu Tiram Interchange - Cahaya } \\
\text { Baru Interchange } \\
\text { Cahaya Baru Interchange - Pasir } \\
\text { Gudang Interchange }\end{array}$ & $\begin{array}{c}\text { Dual 2-lane } \\
\text { carriageway }\end{array}$ & 120 & 3.65 \\
\hline 3 & $\begin{array}{c}\text { Cahaya Baru Interchange - } \\
\text { Penawar Intersection }\end{array}$ & $\begin{array}{c}\text { Single carriageway 2- } \\
\text { lane }\end{array}$ & 90 & 3.50 \\
\hline
\end{tabular}


To investigate the factors related to road accidents, this study had used the 2014 and 2015 detailed collision data of SDE from Senai-Desaru Expressway Berhad. The study period for safety analyses often takes between 3 to 5 years. Relatively short periods of time, such as one year of crash data, are not recommended as the basis for a safety intervention. However, as stated in the Interim Guide from Public Works Department [37], if data from such a long period is not available in the local computer database, shorter periods can be taken into account as long as caution is exercised before any conclusions can be made. This data had included the following key characteristics of each crash: crash date, time of day, direction of travel, location of collision, vehicle types involved, weather conditions, road conditions, light conditions, crash severities and crash types.

The Microsoft Excel Spreadsheet was used for data entry and in the handling of information and search parameters as required for this study. It is worth noting that only accident data along the mainline were considered in the analysis. The appropriate crash pattern for $77.2 \mathrm{~km}$ length was assessed in terms of crash severity, crash type as well as pavement and light conditions. As a way of identifying high-risk road accident locations, the $77.2 \mathrm{~km}$ segment of SDE had been divided into smaller sections of 500m. The purpose of this was to determine the cause or causes of an accident so as to prevent similar kind of mishaps from occurring in the future. This decision was based on the Interim Guide from Public Works Department [37], which stated that the treatment of specific types of accident at a single location usually considered $300-500 \mathrm{~m}$ stretches of road.

There are many approaches to determine high-risk locations. However, based on the data provided, this study had only utilised two methods, namely the Average Crash Frequency Method and the Equivalent Property Damage Only (EPDO) Average Crash Frequency Method. The Average Crash Frequency Method is one of the simplest forms of crash data analysis as it only requires crash data by location. The Crash Frequency performance measure produces a simple ranking of segments according to total crashes or crashes by type and/or severity. This method was used to select two segments with high crash frequency for further analysis. On the other hand, the EPDO Average Crash Frequency performance measure assigns weighting factors to crashes by severity to develop a single combined frequency and severity score per location. The weighting factors are calculated relative to Property Damage Only (PDO) crashes using crash cost by severity. As a way of screening the network, segments were ranked from the highest to the lowest score and two segments with the highest scores were further evaluated for issues and potential countermeasures identification.

\section{Results and analysis}

Figure 2 depicts the pattern analysis for crash severities, crash types, pavement conditions and light conditions for the whole stretch of SDE over a period of 2 years. As shown in Figure 2(a), the severity of accidents had been classified as fatal, injury and property damage only (PDO). The results from crash severities showthat $60 \%$ had resulted in PDO, while $35 \%$ had been on injury severity. The highest percentage of accident type for years 2014 and 2015 (see Figure 2(b)) was run-off-road collision, which had constituted to about $51 \%$ of the accident crashes. This type of crash could be caused by excessive speed, poor roadway lighting and inadequate pavement maintenance. The other types of crashes share almost similar percentages that ranged from $4 \%$ to $14 \%$. It was discovered that $73 \%$ of the crashes had occurred in wet pavement condition, which is shown in Figure 2(c). The possible factors that had led to the accident were slippery pavement and inadequate pavement marking. As shown in Figure 2(d), $71 \%$ of the crashes had occurred during daytime, while $24 \%$ of the crashes had taken place at night. Most of the accidents had mainly involved cars and motorcycles. 


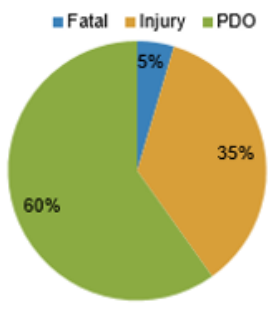

(a) Crash severities

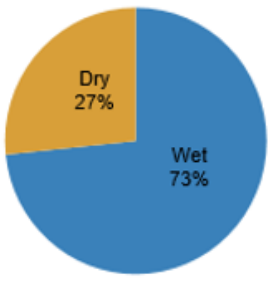

(c) Pavement conditions

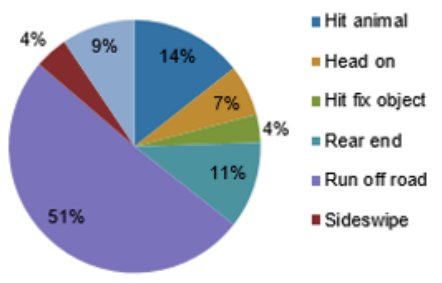

(b) Crash type

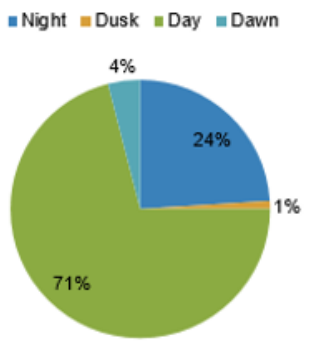

(d) Light conditions

Fig. 2. Crash patterns from 2-year crash history in SDE.

Table 2 provides the corresponding results of Average Crash Frequency Method for total crash, as well as for fatal, injury and PDO crash severities. In this study, the main interest had been on the total crash ranking. Out of the 154 segments, the ranking that was based on total crash showed that segment 150 has the highest crash frequencies, which is followed by segment 25. Table 3, on the other hand, presents the EPDO score that was obtained based on EPDO weights for fatal, injury and PDO crash severities. The highest EDPO score had been from segment 49, which is followed by segment 10 with an EPDO score of 652 .

Table 2. Ranking based on Average Crash Frequency.

\begin{tabular}{|c|c|c|c|c|c|c|}
\hline NO & $\begin{array}{c}\text { SEGMENT } \\
\text { NO. }\end{array}$ & $\begin{array}{c}\text { TOTAL } \\
\text { CRASH }\end{array}$ & $\begin{array}{c}\text { SEGMENT } \\
\text { NO. }\end{array}$ & $\begin{array}{c}\text { FATAL \& } \\
\text { INJURY }\end{array}$ & $\begin{array}{c}\text { SEGMENT } \\
\text { NO. }\end{array}$ & PDO \\
\hline $\mathbf{1}$ & 150 & 10 & 67 & 4 & 150 & 8 \\
\hline $\mathbf{2}$ & 25 & 10 & 49 & 4 & 25 & 8 \\
\hline $\mathbf{3}$ & 51 & 7 & 110 & 3 & 115 & 5 \\
\hline$\ldots$ & $\ldots$ & $\ldots$ & $\ldots$ & $\ldots$ & $\ldots$ & $\ldots$ \\
\hline$\ldots$ & $\ldots$ & $\ldots$ & $\ldots$ & $\ldots$ & $\ldots$ & $\ldots$ \\
\hline $\mathbf{1 5 3}$ & 2 & 0 & 2 & 0 & 2 & 0 \\
\hline $\mathbf{1 5 4}$ & 1 & 0 & 1 & 0 & 1 & 0 \\
\hline
\end{tabular}

Table 3. Ranking based on EPDO Average Crash Frequency.

\begin{tabular}{|c|c|c|c|c|c|}
\hline NO. & SEGMENT NO. & EPDO SCORE & FATAL & INJURY & PDO \\
\hline $\mathbf{1}$ & 49 & 706 & 1 & 3 & 0 \\
\hline $\mathbf{2}$ & 10 & 652 & 1 & 2 & 4 \\
\hline $\mathbf{3}$ & 105 & 650 & 1 & 2 & 2 \\
\hline$\ldots$ & $\ldots$ & $\ldots$ & $\ldots$ & $\ldots$ & $\ldots$ \\
\hline$\ldots$ & $\ldots$ & $\ldots$ & $\ldots$ & $\ldots$ & $\ldots$ \\
\hline
\end{tabular}




\begin{tabular}{|l|l|l|l|l|l|}
\hline 153 & 2 & 0 & 0 & 0 & 0 \\
\hline 154 & 1 & 0 & 0 & 0 & 0 \\
\hline
\end{tabular}

Figure 3 shows the legend for collision diagram. The vehicle types had been classified as such: Class 0 for motorcycle, Class 1 for 2 axle vehicles, Class 2 for 2 axle vehicles ( 6 tires), Class 3 for 3 or more axle vehicles, Class 4 for taxi and finally, Class 5 is for bus. As shown in Figures 4 to 7, the dominant crash severity at segments 10, 25 and 150 had been on PDO, while $75 \%$ of the crashes that occurred in segment 49 had resulted in injuries. Although the rest of the segments had shown run-off-road collision as the dominant crash type, most of the crash type for segment 150 had been on collision with a fixed object. As for pavement and light conditions, segments 10 and 150 had shown the same crash patterns. All of the accidents had occurred during daytime and with dry pavement condition. Among the possible factors that had caused the accidents were inadequate roadway geometric design, poor maintenance, inadequate roadway shoulders and improper road designs. However, segment 25 had shown that the drivers were affected by wet pavement condition. Apart from the human factor, the impact of wet weather and road conditions with poor road geometry designs are among the factors that should be considered in road safety improvement. For segment 49, 50\% of the accidents had occurred on dry and wet pavements as well as during night and daylight conditions. The possible studies and potential countermeasures for the major type of accidents at four selected segments are presented in Tables 4 to 7 [38].

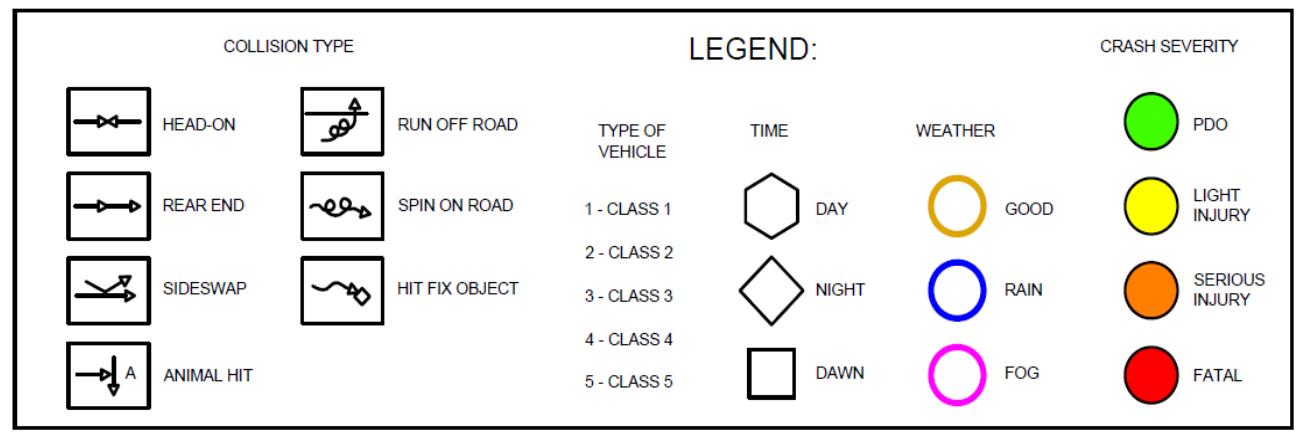

Fig. 3. Legend for collision diagram.

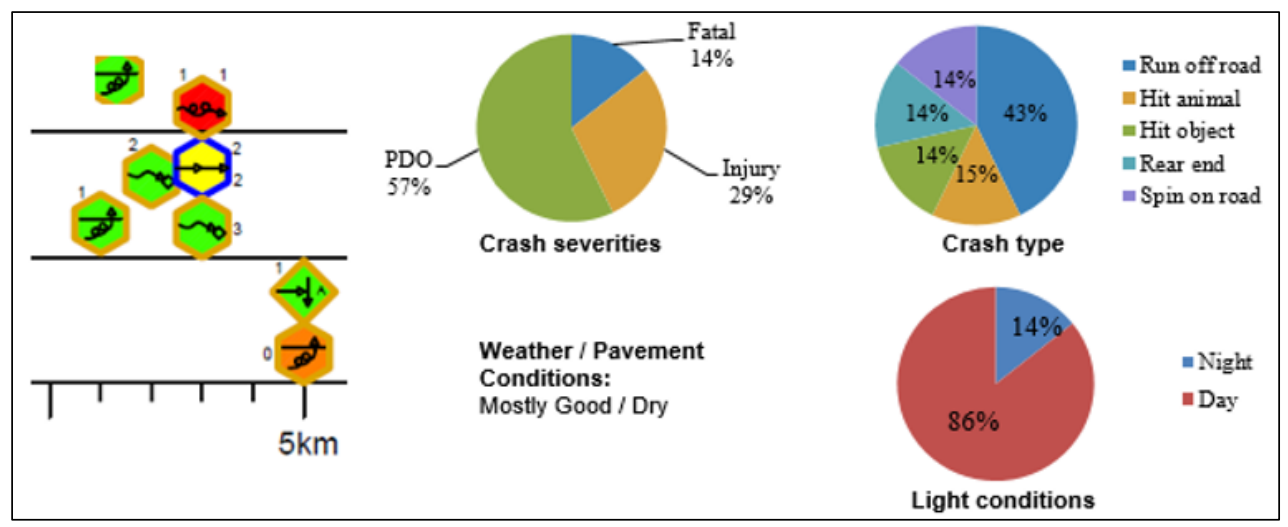

Fig. 4. Segment 10: $\mathrm{km} 4.5-5.0$. 


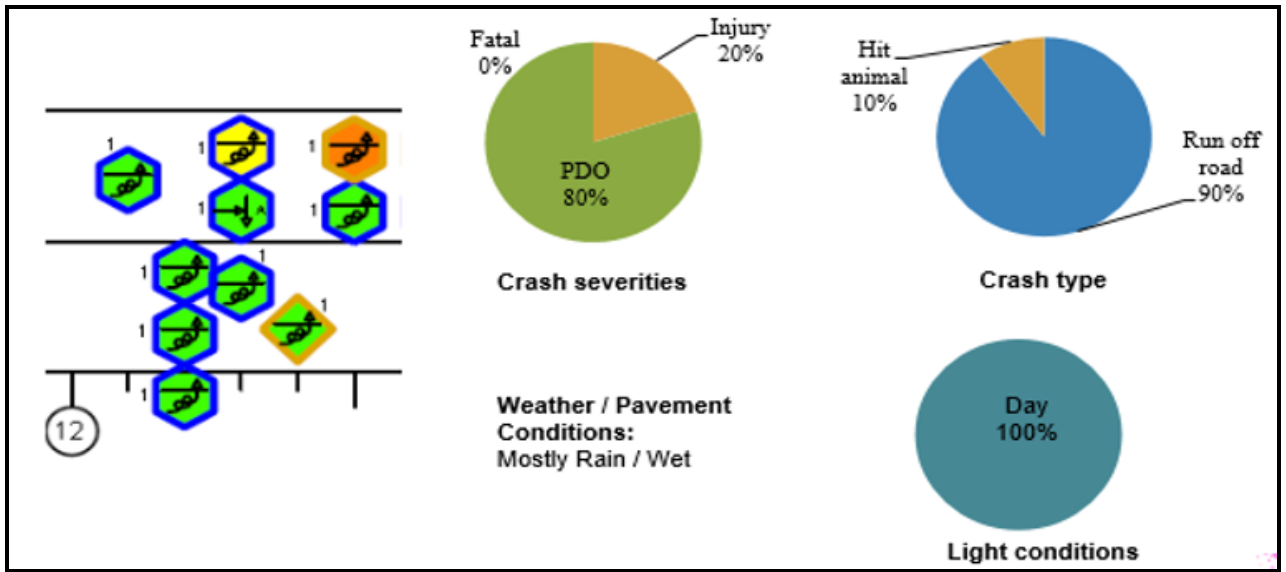

Fig. 5. Segment 25: km $12.0-12.5$.

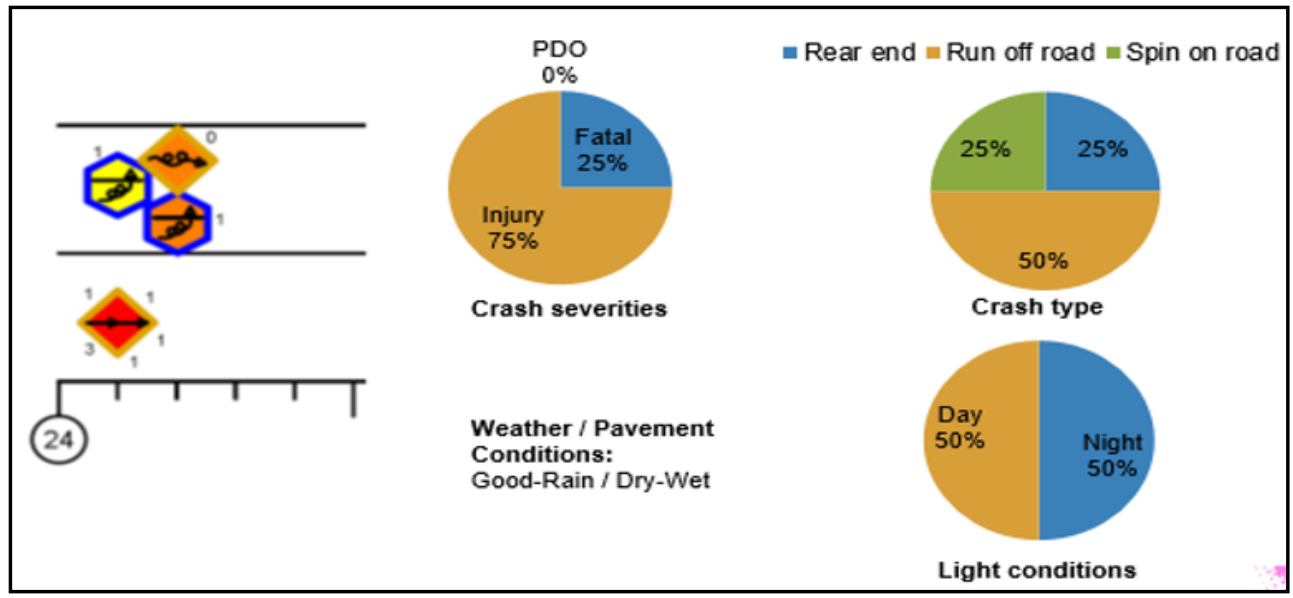

Fig. 6. Segment 49: km 24.0 - 24.5.

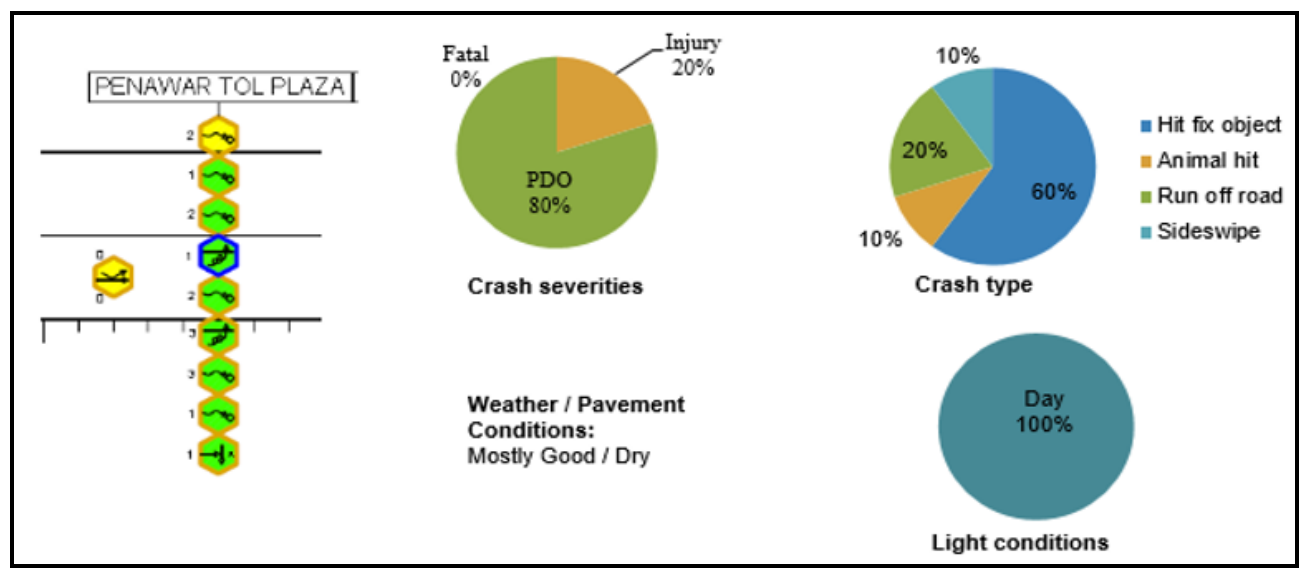

Fig. 7. Segment 150: km 67.5-68.0. 
Table 4. Possible study and safety enhancement for fixed object crash.

\begin{tabular}{|c|c|c|}
\hline Possible Cause & Possible Study & Safety Enhancement \\
\hline $\begin{array}{l}\text { Obstruction in or } \\
\text { too close to } \\
\text { roadway }\end{array}$ & $\begin{array}{l}\text { - Field observation to } \\
\text { locate obstructions }\end{array}$ & $\begin{array}{l}\text { - Delineation/reflectorize safety hardware } \\
\text { - Remove/relocate obstacles } \\
\text { - Install breakaway features to light poles, sign } \\
\text { posts, etc. } \\
\text { - Protect objects with guardrail } \\
\text { - Install crash cushions } \\
\end{array}$ \\
\hline $\begin{array}{l}\text { Inadequate } \\
\text { lighting }\end{array}$ & - Check illumination & • Improve roadway lighting \\
\hline $\begin{array}{l}\text { Inadequate } \\
\text { pavement } \\
\text { markings }\end{array}$ & $\begin{array}{l}\text { - Review pavement } \\
\text { markings }\end{array}$ & $\begin{array}{l}\text { - Install reflectorized pavement lines/raised } \\
\text { markers }\end{array}$ \\
\hline $\begin{array}{l}\text { Inadequate signs, } \\
\text { delineators and } \\
\text { guardrails }\end{array}$ & $\begin{array}{l}\text { Review signs, } \\
\text { delineators and } \\
\text { guardrails }\end{array}$ & $\begin{array}{l}\text { - Install reflectorized paint and/or reflectors on } \\
\text { the fixed object } \\
\text { - Add special signing } \\
\text { - Upgrade barrier system }\end{array}$ \\
\hline $\begin{array}{l}\text { Inadequate road } \\
\text { design }\end{array}$ & $\begin{array}{l}\text { - Check roadside } \\
\text { shoulders and } \\
\text { maintenance } \\
\text { - Check Superelevation } \\
\text { - Perform ball-bank } \\
\text { study }\end{array}$ & $\begin{array}{l}\text { - Install warning signs/delineators } \\
\text { - Improve alignment/upgrade } \\
\text { - Proved proper Superelevation } \\
\text { - Provide wider lanes }\end{array}$ \\
\hline Slippery surface & $\begin{array}{l}\text { - Check skid resistance } \\
\text { - Check for adequate } \\
\text { drainage } \\
\text { - Perform spot speed } \\
\text { study }\end{array}$ & $\begin{array}{l}\text { - Reduce speed limit if justified by } \\
\text { spot speed study } \\
\text { - Provide adequate drainage } \\
\text { - Improve skid resistance }\end{array}$ \\
\hline
\end{tabular}

Table 5. Possible study and safety enhancement for night-time.

\begin{tabular}{|l|l|l|}
\hline \multicolumn{1}{|c|}{ Possible Cause } & \multicolumn{1}{|c|}{ Possible Study } & \multicolumn{1}{c|}{ Safety Enhancement } \\
\hline $\begin{array}{l}\text { Poor visibility or } \\
\text { lighting }\end{array}$ & $\begin{array}{l}\text { ・ Check roadway } \\
\text { illumination }\end{array}$ & $\begin{array}{l}\text { - Install/improve warning signs } \\
\text { Install/improve delineation/markings } \\
\text { - Install/improve street lighting }\end{array}$ \\
\hline Poor sign quality & $\begin{array}{l}\text { - Review signing } \\
\text { Upgrade signing }\end{array}$ \\
\hline $\begin{array}{l}\text { Inadequate } \\
\text { channelization or } \\
\text { delineation }\end{array}$ & $\begin{array}{l}\text { - Review channelization } \\
\text { /delineation }\end{array}$ & $\begin{array}{l}\text { - Install pavement markings } \\
\text { - Improve channelization/delineation }\end{array}$ \\
\hline
\end{tabular}

Table 6. Possible study and safety enhancement for wet pavement.

\begin{tabular}{|l|l|l|}
\hline \multicolumn{1}{|c|}{ Possible Cause } & \multicolumn{1}{|c|}{ Possible Study } & \multicolumn{1}{c|}{ Safety Enhancement } \\
\hline $\begin{array}{l}\text { Slippery } \\
\text { pavement }\end{array}$ & • Check skid resistance & $\begin{array}{l}\text { - Provide 'SLIPPERY WHEN WET' signs } \\
\text { - Reduce speed limit if justified by spot speed } \\
\text { study } \\
\text { - Provide adequate drainage } \\
\text { - Groove existing pavement } \\
\text { - Overlay existing pavement }\end{array}$ \\
\hline $\begin{array}{l}\text { Inadequate } \\
\text { pavement } \\
\text { markings }\end{array}$ & $\begin{array}{l}\text { - Rnstall raised/reflectorized pavement } \\
\text { markings } \\
\text { markings }\end{array}$ & \\
\hline
\end{tabular}


Table 7. Possible study and safety enhancement for run-off-road or spin on road.

\begin{tabular}{|c|c|c|}
\hline Possible Cause & Possible Study & Safety Enhancement \\
\hline $\begin{array}{l}\text { Slippery pavement } \\
\text { / ponded water }\end{array}$ & $\begin{array}{l}\text { - Check skid resistance } \\
\text { - Check for adequate } \\
\text { drainage } \\
\text { - Perform spot speed study }\end{array}$ & $\begin{array}{l}\text { - Reduce speed limit if justified by spot speed } \\
\text { study } \\
\text { - Provide “SLIPPERY WHEN WET' signs } \\
\text { - Provide adequate drainage } \\
\text { - Groove existing pavement } \\
\text { - Overlay existing pavement }\end{array}$ \\
\hline $\begin{array}{l}\text { Roadway design } \\
\text { inadequate for } \\
\text { traffic conditions }\end{array}$ & $\begin{array}{l}\text { - Check roadside } \\
\text { shoulders and road } \\
\text { maintenance } \\
\text { - Check Superelevation } \\
\text { - Perform ball-bank study }\end{array}$ & $\begin{array}{l}\text { - Install/improve traffic barriers } \\
\text { - Close curb lane } \\
\text { - Flatten slopes/ditches } \\
\text { - Relocate islands } \\
\text { - Improve alignment/grade } \\
\text { - Provide proper Superelevation } \\
\text { - Provide escape ramp } \\
\text { - Widen lanes/shoulders }\end{array}$ \\
\hline Poor delineation & $\begin{array}{l}\text { - Review pavement } \\
\text { markings } \\
\text { - Review signs and } \\
\text { placement }\end{array}$ & $\begin{array}{l}\text { - Install roadside delineators } \\
\text { - Install advance warning signs } \\
\text { - Improve/install pavement markings }\end{array}$ \\
\hline Poor visibility & $\begin{array}{l}\text { - Check roadway } \\
\text { illumination }\end{array}$ & $\begin{array}{l}\text { - Increase sign size } \\
\text { - Improve roadway lighting }\end{array}$ \\
\hline $\begin{array}{l}\text { Improper } \\
\text { channelization }\end{array}$ & - Review channelization & - Improve channelization \\
\hline
\end{tabular}

\section{Conclusions}

This study focuses on the findings of accident types that had occurred along the mainline of SDE with the aim of identifying potential issues as well as to propose possible countermeasures that should be taken by the relevant authorities. The findings had verified that:

i. Of all the crashes reported for $77.2 \mathrm{~km}$ segment, $60 \%$ of the crashes had resulted in PDO, while the dominant crash type had beendue to run-off-road collision $(51 \%)$. Also, $71 \%$ of the crashes had occurred during daytime, while $73 \%$ had occurred during wet pavement condition.

ii. Accidents occur because of various factors. As such, the locations with the highest number of crashes (Average Crash Frequency Method) and the highest EPDO score (EPDO Average Crash Frequency Method) had been segments 10 (km 4.5-5.0), 25 ( $\mathrm{km} \mathrm{12.0-12.5),} 49$ ( $\mathrm{km} \mathrm{24.0-24.5)} \mathrm{and} 150(\mathrm{~km}$ 67.5-68.0).

iii. Assessments for the four high risk segments show that the major crash type had been on run-off-road collision. In general, crashes that led to PDO were found to be the highest as compared to fatal and injury crashes. Of all the crashes reported, the majority of accidents had occurred during daytime and on dry pavement condition.

Hence, one of the suggestions for further research is to focus more on the identification of accident causes according to accident type as a way of reducing the number of accidents along the SDE. Apart from that, a review of design requirements should also be conducted by responsible authorities as one of the road safety initiatives.

The authors would like to express their deep gratitude to Malaysian Highway Authority and SenaiDesaru Expressway Berhad for giving opportunity to carry out this research. The authors also would 
like to thank Ministry of Higher Education Malaysia and Universiti Teknologi Malaysia for their financial support (R.J130000.7822.4F867 \& Q.J130000.2522.17H71) and assistance with this research.

\section{References}

1. World Health Organization. Global status report on road safety 2015. Geneva, Switzerland:World Health

Organization, (http://www.who.int/violence_injury_prevention/road_safety_status/2015/en/) (2015)

2. C.J. Murray CJ, A.D. Lopez. The global burden of disease and injury series, Volume 1: A comprehensive assessment of mortality and disability from diseases, injuries, and risk factors in 1990 and projected to 2020. Cambridge. MA, 1 (1996)

3. H. Naci, D. Chisholm, T. D. Baker. Inj. Prev. 15, 55-59 (2009)

4. V.M. Nantulya, M.R. Reich. Br. Med. J. 324, 1139-1141 (2002)

5. M. Khanal, P. Sarkar. J Civil and Environ Eng. S3:001 (2014) http://dx.doi.org/10.4172/2165-784X.S2-001

6. World Health Organization. World report on road traffic injury prevention: summary. 2004. World Health Organization: Geneva (2013)

7. B. O'Neill, D. Mohan. BMJ., 324, 1142-1145(2002)

8. J. Oskam, J. Kingma, H.J. Klasen. Eur. J. Emergency Med. 1, 167-172 (1994)

9. M. Peden. World report on road traffic injury prevention.(2004)

10. D. Shefer, P. Rietveld. Urban Studies 34(4), 679-692 (1997)

11. C. Wang, M.A. Quddus, S.G. Ison. Accid Anal Prev 41 (4), 798-808 (2009)

12. J. Kwon, M. Mauch, M, P. Varaiya. TRR Journal, 84-91 (2006)

13. S. Kumar, D. Toshniwal. J Big Data 2(1), 26 (2015) https://doi.org/10.1186/s40537$\underline{015-0035-y}$

14. A. Kareem. Malays J. Med Sci 10(2), 31-39 (2003).

15. O.R. Babalola, O.O. Adebayo, K.S. Oluwadiya. IOSR Journal of Dental and Medical Science 14(5), 71-75 (2015) https://doi.org/10.9790/0853-14537175

16. P.L. Munteanu, M. Roșu, V. Panaitescu, A. Pungă . J Leg Med. 22, 97-100 (2014)

17. H, Häkkänen, H. Summala. Sleep 23 (1), 49-57 (2000)

18. P. Van Elslande, C. Naing, R. Engel. Analyzing human factors in road accidents: TRACE WP5 Summary Report. Deliverable D5.5 (2008)

19. KementerianKerja Raya Malaysia. Jalan Raya di Malaysia. Kuala Lumpur: KementerianKerja Raya Malaysia (2016)

20. M.Y. Al-Naami, M.A. Arafah, F.S. Al-Ibrahim. Ann Saudi Med 30 (1), 50-58 (2010) http://dx.doi.org/10.4103/0256-4947.59374

21. G. Rechnitzer, N. Haworth, N. Kowadlo. The effect of vehicle Roadworthiness on crash incidence and severity. Report No. 164, Monash University Accident Research Centre (2000)

22. N. Haworth, P. Vulcan, L. Bowland, N. Pronk. Case-control study of fatal single vehicle crashes. Reports No. 120 \& 122, Monash University Accident Research Centre, Australia (1997)

23. R. Haynes, A. Jones, V. Kennedy, I. Harvey, T. Jewell. Environ Plan A, 39 (5), 1222-1237 (2007)

24. J. Kononov, B. Bailey, B. Allery. TRR Journal 26-39 (2008)

25. J.C. Glennon. TRB (6) 48-63 (1987)

26. A. Vogt, J. Bared. TRR Journal 18-29 (1988)

27. O.E.C.D., O.E.C.D. Road Safety Research: A Synthesis (ed.), 106 (1986)

28. L. Aarts, I. van Schagen. Accid Anal Prev 38(2), 215-224 (2006)

29. T.F. Golob, W.W. J Transp Eng, 129(4), 342-353 (2003) 
30. M. Kilpeläinen, H. Summala. Trans Res Part F Traffic Psychol and Behav 10(4), 288299 (2007)

31. M.L. Parry, N.J. Read. The Impact of Climate Variability on UK Industry. Atmospheric Impacts Research Group, School of Geography, The University of Birmingham, 71 (1988)

32. C. Wang. Accid Anal Prev 43, 1979-1990 (2011)

33. F. Chen, S. Chen. Accid Anal Prev 43, 1677-1688 (2011)

34. N. Mashros, J. Ben-Edigbe, S.A. Hassan, N.A. Hassan, N.Z.M. Yunus. J. Teknol 70 (4), 65-69 (2014)

35. M. Hijar. Accid Anal Prev 32, 703-709 (2000)

36. H. Al-Masaeid. Impact of pavement condition on rural road accidents. Can J Civil Eng 24 (4), 523-532 (1997)

37. Transport and road research laboratory. Interim Guide on Identifying, Prioritizing and Treating Hazardous Locations on Roads In Malaysia. Ministry Of Public Works Malaysia (1995)

38. Local Highway Safety Studies - User's Guide, USDOT-FHWA (1986) 